\title{
Differential effects of colleges on the labour market success of their graduates
}

Citation for published version (APA):

Bosker, R. J., van de Loo, P. J. E., \& van der Velden, R. K. W. (1997). Differential effects of colleges on the labour market success of their graduates. Researchcentrum voor Onderwijs en Arbeidsmarkt, Faculteit der Economische Wetenschappen. ROA Research Memoranda No. 1E https://doi.org/10.26481/umaror.199701E

Document status and date:

Published: 01/01/1997

DOI:

10.26481/umaror.199701E

Document Version:

Publisher's PDF, also known as Version of record

\section{Please check the document version of this publication:}

- A submitted manuscript is the version of the article upon submission and before peer-review. There can be important differences between the submitted version and the official published version of record.

People interested in the research are advised to contact the author for the final version of the publication, or visit the DOI to the publisher's website.

- The final author version and the galley proof are versions of the publication after peer review.

- The final published version features the final layout of the paper including the volume, issue and page numbers.

Link to publication

\footnotetext{
General rights rights.

- You may freely distribute the URL identifying the publication in the public portal. please follow below link for the End User Agreement:

www.umlib.nl/taverne-license

Take down policy

If you believe that this document breaches copyright please contact us at:

repository@maastrichtuniversity.nl

providing details and we will investigate your claim.
}

Copyright and moral rights for the publications made accessible in the public portal are retained by the authors and/or other copyright owners and it is a condition of accessing publications that users recognise and abide by the legal requirements associated with these

- Users may download and print one copy of any publication from the public portal for the purpose of private study or research.

- You may not further distribute the material or use it for any profit-making activity or commercial gain

If the publication is distributed under the terms of Article $25 \mathrm{fa}$ of the Dutch Copyright Act, indicated by the "Taverne" license above, 


\title{
Differential Effects of Colleges on the Labour Market Success of their Graduates
}

\author{
ROA-RM-1997/1E
}

Roel J. Bosker*, Rolf K.W. van der Velden** and Peet J.E. van de Loo**

* Department of Educational Administration, Faculty of Educational Sciences and Technology, University of Twente, Enschede, the Netherlands;

** Research Centre for Education and the Labour Market (ROA), Faculty of Economics and Business Administration, University of Limburg, Maastricht, the Netherlands

\section{Research Centre for Education and the Labour Market}

Faculty of Economics and Business Administration

Maastricht University

Maastricht, December 1997 
ISBN 90-5321-224-8

SEC97.165/RvdV 


\section{Contents}

\section{Page}

Abstract

1 Output-based quality control

2 Theoretical background

3 Data and method

4 Results

5 Summary and conclusions

References

Appendix 


\begin{abstract}
This paper explores the effects of colleges for higher vocational education on the labour market success of their graduates. Using data about the labour market position of Dutch graduates from higher vocational education, and applying multi-level statistical modelling techniques it is shown that for four domains (finding a job, level of job, monthly wages, and wages per hour) the colleges did hardly differ substantially. Most of the institutional variation occured at the department level within the colleges, but these department effects appeared to be small as well and not always very stable over the years. The discussion focuses on the implication for using labour market data for the construction of institutional performance indicators. It is shown that the ranking of colleges on their labour market performance changes as soon as input variables are controlled for. It is therefore important to look at the 'net' outcomes or 'added value' rather than the 'gross' outcomes.
\end{abstract}




\section{Output-based quality control}

In most western countries a growing interest in educational indicators can be demonstrated. These indicators are used as summary statistics for measuring the quality of the educational system. The use of key indicators enables policy makers and educational authorities to assess the performance of their educational system, by enabling a systematic comparison of the quality of education between countries, between years, between regions, between institutes or between types of education.

This increase of interest in the public reporting on the functioning of education is due to the following factors:

- a growing awareness that improvement of the quality of education is necessary to increase Europe's competitiveness on a global market and to face the challenges of the future (c.f. European Commission, 1993; IRDAC, 1990);

- constraints on educational budgets due to higher enrollments, forcing the institutes of education to perform more effectively and efficiently;

- increasing demands from consumers (parents and students) to be informed about the quality of educational institutes.

On an international level, the interest in educational indicators can be demonstrated in projects like the Indicators of Education Systems (INES) project of the Organization for Economic Corporation and Development (OECD/CERI, 1996; see also Tuijnman and Postlethwaite, 1994) or the Educational Indicators Project (CEIP) from the European Commission (West et al., 1995). The interest in quality of education is also demonstrated in the Maastricht Treaty on the European Union (article 126, chapter 3): 'the European Community shall contribute to the development of quality education....' and in subsequent action programmes like SOCRATES and LEONARDO. On a national level, similar projects can be identified, regarding the educational performance on a national level as well as a regional and institutional level (Willms and Kerckhoff, 1995; Croxford and Cowie, 1996; Ministry of Education, Culture and Science, 1995; Fitz-Gibbon, 1996; Willms, 1992).

In the Netherlands, quality assessment in higher education has been on the public policy agenda since the publication in 1985 of the paper "Higher Education: Autonomy and Quality" by the Dutch Ministry of Education, Culture and Science. This paper marked a change in the administrative relation towards higher education. Instead of a direct control of the contents and quality of higher education, the Ministry placed higher emphasis on autonomy and selfregulation for the institutes of higher education (colleges for higher vocational education and universities). This was to be accompanied by a system of quality assurance in which the institutes of higher education give an account of their performance.

This system of quality assurance covers all areas of the educational process, such as inflow of students, study progress (internal output), input of staff and other resources, but also business administrative aspects. One of the major issues in the system of quality 
assurance is the so-called external output of education, that is the success of graduates on the labour market.

One problem that may be raised here is that not all differences in the performance of colleges can be attributed to organizational or educational factors. Instead, some of the differences between colleges reflect merely differences in student composition or regional differences in the labour market, factors for which the colleges cannot be held responsible. Another issue is that these differences are not always systematic, but rather subject to major variations over time. This indicates that at least part of the differences must be attributed to sample fluctuations.

In this paper we explore the following questions:

1. Do colleges of higher vocational education vary in the mean success of their graduates on the labour market, even after controlling for student and region characteristics?

2. Are the differences between these colleges stable over time?

\section{Theoretical background}

The analysis in this paper draws upon three lines of research: educational effectiveness, quality assurance and labour market research.

The educational effectiveness literature has its origin in the work of Coleman et al. (1966), who tried to assess the factors (school resources mainly) that could account for the value schools added to students learning, i.e. by controlling for intake differences between schools. Despite the marginal effects discovered by the authors the quest for which factors matter in education continued. One line of further research was on school and instructional effects (Scheerens and Bosker, 1997), whereas the other converged with the economic tradition of education production function research (Hanushek, 1986; Monk, 1989; Dolan and Schmidt, 1994). The first demonstrated that schools affect the achievement of their students to a small but relevant degree, and succeeded in singling out effectiveness enhancing factors like monitoring practices within schools and achievement pressure for basic subjects. The results of the research into the educational production function (looking for effects of resource variables like pupil-to-teacher ratio, per pupil expenditure, and teachers' salaries, training and experience) produced less convincing results, although a reanalysis of the evidence by Hedges et al. (1994) using statistical meta-analysis procedures resulted in some support for per pupil expenditure being an output enhancing factor. Within these research traditions, however, no mention is made of research into the labour market outcomes. Most of the research concentrates on academic performance or on school careers. This, of course, is caused by the fact that most research concentrates on primary education. However, one might argue that differences in the educational output will also be reflected in differences in labour market outcomes. The effects of educational institutions on labour market outcomes however will probably be less strong, because of the interve- 
ning effects of other factors.

The second line of research which bears relevance for our analysis relates to research into quality assurance and the use of performance indicators in higher education. Quality assurance, planning and resource allocation, particularly during times of financial (governmental) constraints and changing socio-economic demands, involves making choices between mutually exclusive alternatives each with its own combinations of inputs, outputs, outcomes, impacts and benefits (e.g. Segers, 1993). At the one hand the institutions of higher education obtained a greater autonomy with respect to the input and process factors. On the other hand the institutions are being called more and more to account for their output. Effectiveness and efficiency became central concepts: higher education became responsible to manage their institutions by themselves. In this framework it is relevant to mention that De Jager (1994) shows that the relationship between the organizational context and structure, and the 'paradigms' of the higher vocational colleges have an impact on the outcomes of educational policy. These paradigms refer to the pedagogic or professional role of the staff, the educational mission and internal coalition of the college.

Countries like the United Kingdom, Australia and the Netherlands adopted ideas and tools of the U.S. accreditation system. In the Netherlands this lead to a nation wide and public quality assurance system of visiting committees. All institutions taking care of a discipline are visited periodically. It is a rolling review process with two complementary phases: internal evaluation by the faculty, reported in a self-study report and visitations by external peers. A checklist, consisting of a set of performance indicators, the operationalization of the dynamic and multidimensional concept of quality, is the guideline for the faculty report and the comments of the visiting committee. The relevance of the training with respect to the requirements of the labour market and professional practice are more and more considered as important indicators to judge the quality of a higher (vocational) educational discipline. Since decentralization and deregulation of national educational policies resulted in more autonomy for educational institutions demanding quality assurance was one of the means for national governments to control quality. One of the other means, especially used in the USA and in the United Kingdom, was the idea of creating a quasi-market mechanism by publishing process and output data regarding the performance of educational institutions (e.g. O'Leary, 1996). The performance indicators themselves and the procedures used to construct them are, however, heavily criticized (e.g. Morrison et al., 1995; Goldstein and Myers, 1996; Yorke, 1997), with one of the criticisms being that the indicators do not reflect the value added by the educational institutions, but that the output indicators are to a large degree simple reflections of differences in student input instead.

The third line of research of relevance here is the labour market research. The leading assumption in human capital and matching theory is that education and training makes people more productive. Following education can therefore be seen as an investment in human capital (Becker, 1975; Schultz, 1961) which increases productive skills and will therefore lead to higher wages. In most research the focus of interest has been on 
explaining differences between types of education, rather than between institutes of education. A few authors point to the relevance of differences between colleges. Glebbeek (1989) regards education as a production process with an important feature: the variability in outcomes. Unlike most production processes, the output of education is characterised by a large variation in quality. Graduates vary considerably in acquired skills and this variation is closely linked to the selectivity of the educational process. Colleges that put high standards in their exams, will produce an output with higher quality and less variation. As employers have no means of assessing directly the productive skills of an individual, this variation in quality produces a considerable risk. Especially in branches in which mediocre functioning of employees produces a high risk (like health care), this could lead to additional educational requirements. Empirical evidence for this relation between the quality of a college and overeducation is given by Robst (1995). In a paper examining the relation between college quality and overeducation, he shows that workers who attended a lower quality college have a higher likelihood of ending up in a job for which they are overeducated. In the Netherlands Van der Velden et al. (1989) have shown that the following factors are relevant for the labour market outcomes: high selectivity during the training, an appropriate match between education and occupation, effective instruction and career guidance activities.

In this paper we restrict the analysis to the question whether there are any differences between colleges of higher vocational education after controlling for student and regional factors and leave aside the question to which factors these differences may be attributed. Bearing in mind the results of the educational effectiveness literature, we expect only modest differences between colleges in the labour market outcomes. Moreover, we expect these differences to be larger for employment chances than for outcomes which are more institutionally defined (e.g. wages).

\section{Data and method}

In 1991, the Dutch Council for Higher Vocational Education (HBO-Raad) commissioned the Research Centre for Education and the Labour Market (ROA) to develop an instrument which assesses the success of graduates on the labour market and which could be used in the system of quality control by institutes of higher vocational education. This instrument has been in operation as of 1991. About two thirds of all the colleges make use of it, which makes it the most important instrument for external quality control.

The instrument consists of an annual survey among graduates of the participating colleges. In this survey, information is collected about destination, labour market entry, unemployment spells, and the jobs that the graduates hold. The survey is held one and a half year after graduation.

The participating institutes of higher vocational education receive standard information 
about the results of their own graduates in confidential institute reports. This information can directly be compared with the national figures for the types of education in question. Apart from this, a national, public report is published where the results of the total outflow of a particular sector of higher vocational education is analyzed (see Van de Loo and Van der Velden, 1994).

In this analysis, data is used from the 1991, 1992 and 1993 survey (Van de Loo et al., 1992; Van de Loo et al., 1993; Van de Loo and Van der Velden, 1994). This means that the target population consists of graduates from higher vocational education from the following cohorts: 1989/90,1990/91 and 1991/92. These cohorts have each entered the labour market under different situations. We restrict the dataset to graduates from the largest types of training within the following six sectors of higher vocational education: pedagogics, technics, economics, health studies, social studies and fine arts. The selected courses are: teacher training (for primary education), mechanical engineering, business administration, nurse training, social work training and music (teacher) training.

In the analysis the following dependent variables are used: a dummy indicating if the graduate was less than 3 months unemployed during the job entry period ("job entry"), a dummy indicating if the level of the job corresponded to the level of higher education ("level of job") ${ }^{1}$ and two indicators for income ("gross hourly wage" and "gross monthly wage") ${ }^{2}$.

The predictor variables include personal characteristics (sex, age) as well as qualification and skills characteristics like training course in higher vocational education, previous type of education, previous job experience, board experience ${ }^{3}$ and length of study. The first column includes all graduates who entered the labour market. The second column includes only those who hold a job at the time of the interview. To control for regional and annual (business cycle) variations on the labour market we include the region where the college is situated, the region where the graduate is employed, and year of survey.

Table 1 presents some descriptive statistics. Some $15 \%$ of the graduates were more than three months unemployed during the period between graduation and the survey. At the moment of the survey $79 \%$ held a job which matched their educational level. The gross monthly wages amounted to 2,880 Dutch guilders, while the gross hourly wage was slightly more than 18 guilders on average.

Table 1

Means (standard deviations) and percentages

1. Zero corresponding with a job level lower than higher education (overeducation).

2. The difference between these two variables of course is, that monthly wage is dependent on whether it concerns a parttime or a fulltime job, whereas hourly wages is not.

3. Board experience includes having been board member of a corporation, but also having been a club's, society's, or association's officer. 


\section{Dependent variables}

job entry

- quick ( $\leq 3$ months)

$85.3 \%$

n.a

- slow

$14.7 \%$

level of job

n.a.

- lower than higher vocational

$20.9 \%$

- at least higher vocational

$79.1 \%$

wages per hour (fl)

n.a.

$18.29(4.23)$

monthly wages $(\mathrm{kfl})$

n.a.

\section{Predictor Variables}

Student level

$N_{s}=6275$

$N_{s}=4303$

sex

- female

$60.0 \%$

$62.0 \%$

- male

$40.0 \%$

$37.8 \%$

preliminary education

- senior general

$46.5 \%$

$45.5 \%$

- pre-university

$31.1 \%$

$19.6 \%$

$31.3 \%$

$20.6 \%$

- senior vocational

$0.9 \%$

$0.7 \%$

- other education

$1.9 \%$

$2.0 \%$

job experience

- yes

$33.8 \%$

$34.0 \%$

- no

$66.2 \%$

$66.0 \%$

board experience

- yes

$25.2 \%$

$25.2 \%$

$74.8 \%$

$74.8 \%$

age

$24.63(2.05)$

$24.70(2.06)$

length of study (in years)

$4.05(0.63)$

$4.03(0.62)$

region of work

n.a.

$48.7 \%$

$6.5 \%$

- north

$20.7 \%$

- east

$22.5 \%$

- south

$1.6 \%$

Table 1 (continued)

Means (standard deviations) and percentages 


\begin{tabular}{|c|c|c|}
\hline year level & $N_{y}=223$ & $N_{y}=223$ \\
\hline \multicolumn{3}{|l|}{ year } \\
\hline-1991 & $28.7 \%$ & $28.7 \%$ \\
\hline - 1992 & $34.1 \%$ & $34.1 \%$ \\
\hline - 1993 & $37.2 \%$ & $37.2 \%$ \\
\hline department level & $\mathrm{N}_{\mathrm{d}}=97$ & $N_{d}=97$ \\
\hline \multicolumn{3}{|l|}{ study } \\
\hline - pedagogics & $25.8 \%$ & $25.8 \%$ \\
\hline - technics & $18.6 \%$ & $18.6 \%$ \\
\hline - economics & $15.5 \%$ & $15.5 \%$ \\
\hline - health studies & $17.5 \%$ & $17.5 \%$ \\
\hline - social studies & $16.5 \%$ & $16.5 \%$ \\
\hline - fine arts & $6.2 \%$ & $6.2 \%$ \\
\hline college level & $N_{c}=50$ & $N_{c}=50$ \\
\hline \multicolumn{3}{|l|}{ region } \\
\hline - west & $42.0 \%$ & n.a. \\
\hline - north & $10.0 \%$ & \\
\hline - east & $26.0 \%$ & \\
\hline - south & $22.0 \%$ & \\
\hline
\end{tabular}

n.a. $=$ not applicable

A majority $(60 \%)$ of the sample used for this analysis is female ${ }^{4}$. The mean age is 25 years. About a quarter of the graduates had board experience before entering the labour market and about one third had previous job experience. Senior general secondary education is the dominant type of previous education, followed by pre-university education and senior vocational secondary education ${ }^{5}$.

The number of graduates from higher vocational education is (still) increasing. This is not only the case in this analysis but also in the total amount of this population in the Netherlands. The western part of the Netherlands is both dominant in the educational field, and in

4. This is due to the fact that the male graduates more often than the female graduates of higher vocational education continue their educational career (Van de Loo et al. (1992-1994)). In this analysis graduates that continued studying (e.g. in university) are excluded. The analysis only involves the labour force. In general, women comprise only half of the population of graduates from Higher Vocational Education.

5. Senior general secondary education (HAVO) has a duration of 5 years after primary education and is supposed to be the main route to higher vocational education. Pre-university education (VWO: duration 6 years) is supposed to prepare for university education, although an important share of its graduates go on to higher vocational education. Senior vocational secondary education (MBO: duration 3-4 years), which is the normal route for further education for students graduating from intermediate general secondary education (MAVO: duration 4 years) or from junior vocational education (LBO: duration 4 years), prepares mainly from the labour market although it has an increasing share of graduates following further education. 
the employment. For the northern and eastern regions there is a negative net migration flow of graduates to this dominant western part in the Netherlands.

The design is nested and consists of the following levels: student, year, department (sector of college) and the college level. As we selected only one course per sector, the department level coincides with the training course. We restrict the dataset to those graduates who, at the moment of the survey, belong to the labour force (employed plus unemployed). This amounts to a total of 6,275 cases $^{6}$. These were nested in 223 year/department/college combinations. These combinations were nested in 97 department/college combinations and these again were nested in 50 different colleges. Because of the hierarchical datastructure a multilevel statistical model is applied (Bryk and Raudenbush, 1992; Goldstein, 1995; Longford, 1993).

The multi-level model specification is as follows:

$$
\begin{aligned}
& y_{\text {sydc }}=B_{\text {oydc }}+B_{1} \text { SEX } X_{\text {sydc }}+\ldots+B_{12} \text { FOREIGN }_{\text {sydc }}+e_{\text {sydc }} \quad \text { student-level } \\
& B_{\text {oydc }}=B_{00 d c}+Y_{1} 1992_{y d c}+\gamma_{2} 1993_{y d c}+u_{0 y d c} \quad \text { year-level } \\
& B_{00 d c}=B_{000 c}+\delta_{1} T C_{d c}+\ldots+\delta_{5} A R T S_{d c}+v_{00 d c} \quad \text { department-level } \\
& B_{000 c}=B_{0000}+\zeta_{1} \text { NORTH }_{c}+\ldots+\zeta_{3} \text { SOUTH }_{c}+w_{000 c} \quad \text { college-level }
\end{aligned}
$$

In (1) $Y_{\text {sydc }}$ is the score on the dependent variable for student $s$ in year $y$ in department $d$ of college c. This score is regressed on twelve student-level predictors with associated regression coefficients $B_{1}$ to $B_{12}$. In the estimation procedure each of these are estimated as a sort of weighted average of a pooled within year/department/college specific regression coefficient and an across all students regression coefficient. $B_{0 y d c}$ is the value for the intercept (i.e. the score when all the predictors have a value of zero) for year $y$ in department $d$ of college $c$. Since all regression coefficients are fixed the variation in $B_{\text {oydc }}$ equals the variation in for student-level predictor differences corrected year/department/college averages. In its turn this average is regressed on two year-level predictors (two dummies to represent the three years) with associated regression coefficients $Y_{1}$ and $Y_{2}$. The precision with which these regression coefficients are estimated depends more on the number of year/department/college combination than on the number of students (c.f. Snijders and Bosker, 1993). $B_{00 d c}$ represents the score for department $d$ in college $c$ when all the student- and year-level predictors take on the value of zero. These then are regressed on five department-level-dummy-variables representing the six sectors within higher vocational education, and in (4) the college-level equation is given (with three

6. For the analysis of job entry the total sample could be used. For the other three analyses the sample was restricted to those graduates who held a job at the moment of the survey. This amounts to 4,303 cases. 
dummies as predictors representing the four regions).

Furthermore it is assumed that $e_{\text {sydc }} \sim N\left(0, \sigma_{e}^{2}\right), u_{\text {oydc }} \sim N\left(0, \sigma_{u}^{2}\right), v_{00 d c} \sim N\left(0, \sigma_{v}^{2}\right)$, and that $w_{000 c}$ $\sim \mathrm{N}\left(0, \sigma_{\mathrm{w}}^{2}\right)$, i.e. all residuals are normally distributed with zero mean and some (unknown) variance. By definition the residuals are uncorrelated. Regression and variance component parameters are estimated using maximum likelihood.

For the logistic multi-level regression model, applied to model the binary dependent variables ("job entry" and "level of job") the logistic link function is used (Wong and Mason, 1985; Bosker and Hofman, 1994). In this case it is assumed that

$\left(\mathrm{y}_{\text {sydc }} \mid \mathrm{p}_{\text {sydc }}\right) \sim \operatorname{Bernouilli}\left(\mathrm{p}_{\text {sydc }}\right)$

where $p_{\text {sydc }}=P R\left(y_{\text {sydc }}=1\right)$ is the probability that student $s$ from year $y$ in department $d$ of college $\mathrm{c}$ will have a job respectively will have an appropriate job. Instead of $\mathrm{y}_{\text {sydc }} \operatorname{logit}\left(\mathrm{p}_{\text {sydc }}\right)$ will be regressed on the predictors. In this case (1) does not contain a residual, i.e. $e_{\text {sydc }}=0$. Parameters are estimated using penalized quasi-likelihood estimation (Longford, 1993; Goldstein, 1995).

The results will indicate that colleges hardly differ in their average performance, but that departments do. For that reason the second research question (see section 1) will be modified into an exploration of the stability of departmental performance. The stability of the performance of the departments is estimated by taking the ratio of the sum of the estimated between departments and colleges variance to the sum of the estimated between years, between departments and between colleges variance:

$\left(\hat{\sigma}_{v}^{2}+\hat{\sigma}_{w}^{2}\right) /\left(\hat{\sigma}_{u}^{2}+\hat{\sigma}_{v}^{2}+\hat{\sigma}_{w}^{2}\right)$

Since the random effects are modelled explicitly, this is the 'true' stability (cf. Willms and Raudenbush, 1989).

The performance indicators then are constructed using 'shrinkage estimators' (e.g. Bryk and Raudenbush, 1992), in which precision weights are used to estimate the department parameters:

$B_{d c}^{*}=w_{d c} B_{d c}+\left(1-w_{d c}\right) B^{*}$

$B$ is the Ordinary Least Squares estimator (in models without predictors this is the mean), $w_{d c}$ the precision weight and $B^{*}$ the Empirical Bayes estimate of the population mean (across the departments and colleges). These precision weights are the ratio's of the estimated true between department level variance relative to the observed between department level variance: 
$\mathrm{w}_{\mathrm{dc}}=\hat{\sigma}_{\mathrm{v}}^{2} /\left(\hat{\sigma}_{\mathrm{v}}^{2}+\left(\hat{\sigma}_{\mathrm{u}}^{2}+\hat{\sigma}_{\mathrm{e}}^{2} / \mathrm{n}_{\mathrm{ydc}}\right) / \mathrm{n}_{\mathrm{dc}}\right)$

$\mathrm{n}_{\mathrm{ydc}}$ is the number of students in year $\mathrm{y}$ in department $\mathrm{d}$ in college $\mathrm{c}$ and $\mathrm{n}_{\mathrm{dc}}$ is the number of years in department $d$ in college $c$.

The gross performance indicators are constructed estimating the parameters without predictors at the student and college level, but with as predictors year and study since including these may result in corrections for conjunctural fluctuations and study specific employment opportunities. The net performance indicators are constructed estimating parameters in regression models that contain all predictors. Comparing departments is, of course, not only done on the basis of point estimates for the performance indicators, but using confidence intervals as well. Goldstein and Healy (1995) have argued that, when comparing two institutions out of a larger number, confidence intervals are tighter. When comparing institutions amongst each other the $90 \%$-confidence interval should be derived from (Goldstein and Healy, 1995, p. 2)

$Y=2\left[1-\Phi\left\{1.64\left(\sigma_{1}+\sigma_{2}\right) / \sigma_{12}\right\}\right.$

in which $\Phi$ is the normal integral, $\sigma_{1}$ is the standard error of the mean for the first and $\sigma_{2}$ for the second institution, and $\sigma_{12}$ is the standard error of the grand mean. $y$ then is the new standard normal score that should be used to construct the $90 \%$-confidence interval (and usually this value is considerable smaller than 1.64). For a series of means $Y_{i j}$ is determined for each pair of institutions $\mathrm{i}$ and $\mathrm{j}$, and then $\overline{\mathrm{y}}$ is used.

These comparisons often result in rankings, and we will do this as well. But in ranking the departments different ranks are assigned if the departments have significantly different scores on the performance indicators. First of all it is determined for a department $d$ in a college $c$ how many of the departments have a statistically significant higher score: $N(H)_{d c}$. Then it is determined how many departments have a statistically significant lower score than department $d$ in college $c: N(L)_{d c}$. The "conservative" percentile rank $R(C)_{d c}$ then is calculated as (with $\mathrm{N}_{\mathrm{dc}}$ being the total number of departments):

$R(C)_{c}=100 *\left\{\left(N(H)_{d c}+N(L)_{d c}\right) / 2 N_{d c}\right\}$

The result of this conservative ranking procedure is, that ranks are less dispersed, which reflects the fact that differences between departments are smaller than a complete ranking would have suggested.

\section{Results}

As indicated before, a 4-level hierarchical model is used for the analysis with levels student, year, department, and college. For the dummy variables "job entry" and "level of job" we 
adopted a logistic regression approach. Table 2 presents the results of the 4-level analyses with predictors year of survey and type of training only. The rankings of the departments on the basis of these mean gross outcomes for their graduates are presented in the Appendix.

Table 2

Results of the (logistic) 4-level analyses. Regressions coefficients and standard errors (between brackets)

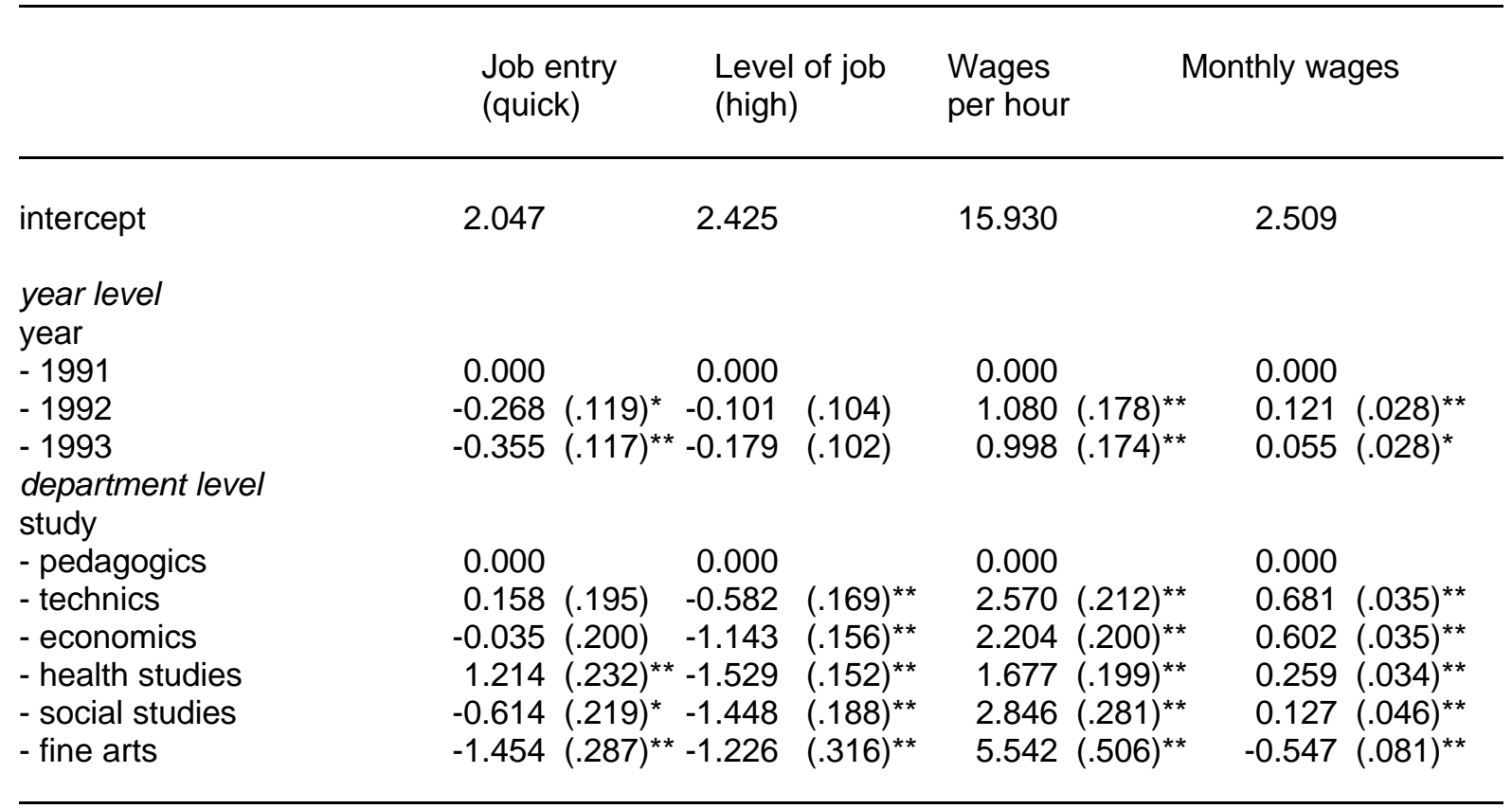

$\because p<.05$

$: p<.01$

Compared to the situation in 1991 the labour market opportunities for graduates worsened in 1992 and 1993 (see Table 2), due to a harsh recession at the beginning of the nineties, resulting in significantly lower proportions of graduates who were less than 3 months unemployed. The effects for 1992 and 1993 as compared to 1991 are estimated to be -0.268 and -0.355 respectively. In general, school-leaving graduates are the first to be affected by a recession, because employers do react by firing their (regular) personnel, but cease the recruitment at first. This decrease in employment opportunities was not accompanied by a significantly lower level of the jobs acquired, although the negative signs for 1992 and 1993 suggests that the proportion of graduates who hold a job below their educational level has grown. The hourly and monthly wages in 1992 and 1993 are significantly above the 1991 level $^{7}$ (approximately 1 Dutch guilder). Between 1992 and 1993 there is a drop in the mean monthly wages $(0.055-0.121=-0.066)$, which may be attributed to an increase in part-time work and lower level jobs.

There are significant differences between the types of studies in labour market outcomes.

7. A small part of these year-to-year wage differences could be attributed to small deviations in the survey on wage subjects. Moreover, wages have not been controlled for inflation rate. 
Compared to pedagogics, graduates from health studies show significantly higher proportions of quick job entry while the graduates from social studies and fine arts suffer significantly more from (temporary) unemployment.

The analysis with respect to level of job shows the typical features of the labour market for teachers, where job entry is ruled by specific demands regarding the proper qualifications and where most of the graduates become teacher. On the other side, especially the graduates from health or social studies, and to a somewhat lesser degree graduates from economics, fine arts, and technics as well are found in labour market segments for secondary educated graduates, which implies that they are overeducated.

The hourly wages for graduates from pedagogics are the lowest of all 6 training courses, which is the result of a separate, compulsory, and low paid, wage scale for beginning teachers in the Netherlands. The same applies for the monthly wages, with one exception: the graduates from fine arts have lower monthly wages because of a larger proportion of people holding part-time jobs.

Table 3 shows the residual variance components at the different levels ${ }^{8}$. For the analysis on job entry, we see that there are significant differences in the mean outcomes at all 3 levels. Of the total residual variance of $0.316(=0.072+0.143+0.101)$ at higher levels, $23 \%$ can be attributed to differences within departments between the years, $45 \%$ to differences between the different departments within a college, and the resulting $32 \%$ to differences between colleges. In other words, from the total amount of differences between departments and colleges over the years, $23 \%$ is due to change, or put alternatively: the stability of department effects for job entry over time amounts to 0.77 .

For the analysis on level of job, we only detect systematic differences between departments, with no variation over time and no differences between colleges. In this case the stability of department effects over time thus is perfect.

For the analysis on hourly wages the picture is quite different. The total variance amounts to 16.070 , only $1 \%$ of which can be attributed to differences between departments over the years. The stability of these department effects is zero: all differences found are due to variation over time within departments. In the analysis on monthly wages it appears that there are no differences between departments within colleges, but since the colleges do differ (and so do departments from different colleges) the stability of the departments can be estimated as being 0.38 .

Table 3

Results of the (logistic) 4-level analyses for 'gross' performance indicators; residual variance components

8. At the student level there is no variance component for the logistic analyses, because the dependent variable is a dummy. 


\begin{tabular}{llccc}
\hline & Job entry & Level of job & Wages per hour & Monthly wages \\
\hline student level & n.a. & n.a. & 16.070 & 0.380 \\
year level & 0.072 & 0.000 & 0.180 & 0.005 \\
department & 0.143 & 0.059 & 0.000 & 0.000 \\
college level & 0.101 & 0.000 & 0.000 & 0.003 \\
\hline
\end{tabular}

Table 4 presents the results of the (logistic) 4-level analyses after controlling for student and regional factors. The results regarding the type of training followed and the year of survey, are very similar to the former results in table 2.

Regarding the effects of personal characteristics, we note that males earn 0.4 guilders per hour more than females. Per month the difference amounts to 134 Dutch guilders in favour of males. This is remarkably at the beginning of the careers, as most female higher education graduates have not interrupted their professional careers yet. Age decreases the chances of being less than 3 months unemployed, but once a job is found it also increases the wages earned.

The type of previous education followed only has an effect on the job entry: graduates who have followed senior vocational secondary education before entering their course in higher vocational education, have a higher chance of being less than 3 months unemployed. Having job experiences before graduation increases the employment chances and also increases the monthly wages by 51 guilders. There is no significant effect of board experience. Graduates who finish their study in a relatively short time, increase their chances of being less than 3 months unemployed and also increase their chances of acquiring a job which matches their educational level.

Finally, regional differences in the labour market situation affect the labour market outcomes. Graduates who attended college in the western part of the Netherlands, have significantly higher chances of being less than 3 months unemployed than those who attended college in the south, the east and especially the north. It is likely that these regional differences mainly are the result of regional employment differences, although the possible better acquaintance and image of the western colleges for employers (in the

Table 4

Results of the (logistic) 4-level analyses for 'net' performance indicators. Regressions coefficients and standard errors (between brackets)

\begin{tabular}{lllll}
\hline & $\begin{array}{l}\text { Job entry } \\
\text { (quick) }\end{array}$ & $\begin{array}{l}\text { Level of job } \\
\text { (high) }\end{array}$ & $\begin{array}{l}\text { Wages } \\
\text { per hour }\end{array}$ & Monthly wages \\
\hline GRAND MEAN & 5.678 & 3.076 & $1.797(0.141)$ & 8.526
\end{tabular}


student level

Sex

- female

$\begin{array}{rllllll}0.000 & & 0.000 & 0.000 & 0.000 & \\ 0.101 & (0.102) & 0.025(0.109) & 0.126(0.026)^{* *} & 0.392 & (0.171)^{*} \\ -0.112(0.022)^{* *} & 0.016(0.023) & 0.034(0.006)^{* *} & 0.342 & (0.036)^{* *}\end{array}$

age

Preliminary education

- higher general

- pre-university

- senior vocational

- higher vocational

- other education

length of study

job experience

- no

- yes

board experience

- no

- yes

region of work

- west

- north

- east

- south

- foreign

year level

year

- 1991

- 1992

- 1993

department level

pedagogics

- technics

- economics

- health studies

- social studies

- fine arts

college level

region

- west

$\begin{array}{rrrrrrr}0.000 & 0.000 & 0.000 & 0.000 & \\ -0.005(0.099) & -0.021 & (0.100) & -0.014 & (0.024) & 0.031 & (0.154)\end{array}$

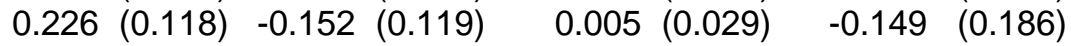

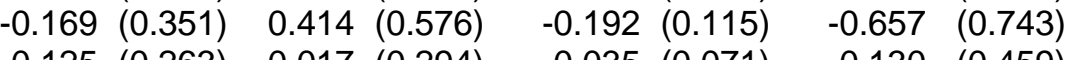

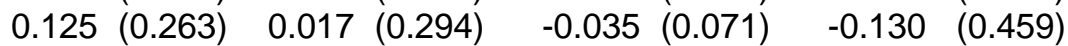

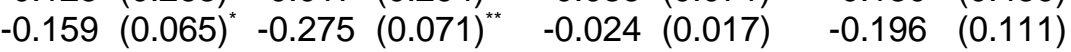

$\begin{array}{lllllll}0.000 & 0.000 & 0.000 & 0.000 & \\ 0.208(0.090)^{*} & 0.136(0.087) & 0.048(0.021)^{*} & 0.159 & (0.136)\end{array}$

$\begin{array}{lllllll}0.000 & 0.000 & 0.000 & 0.000 & \\ 0.080(0.090) & 0.160(0.094) & 0.019 & (0.022) & 0.145 & (0.140)\end{array}$
n.a.

$\begin{array}{rrrrrl}0.000 & & 0.000 & & 0.000 & \\ -0.148 & (0.177) & -0.171 & (0.044)^{* *} & -0.372 & (0.262) \\ 0.086 & (0.116) & -0.121 & (0.028)^{\star *} & -0.356 & (0.165)^{\star} \\ 0.083 & (0.116) & -0.082 & (0.029)^{\star *} & -0.307 & (0.163) \\ 0.368 & (0.335) & 0.667 & (0.074)^{\star *} & 4.242 & (0.481)^{\star *}\end{array}$

$\begin{array}{rrrrrr}0.000 & 0.000 & 0.000 & 0.000 & \\ -0.285(0.115)^{*} & -0.128(0.105) & 0.122(0.027) & 1.081 & (0.170)^{* *} \\ -0.346(0.113)^{*} & -0.196(0.103) & 0.052(0.027) & 0.971 & (0.165)^{* *}\end{array}$

$\begin{array}{lrllll}0.000 & 0.000 & 0.000 & 0.000 & \\ 0.150(0.206) & -0.436(0.196)^{*} & 0.554(0.042)^{\star *} & 1.963 & (0.255)^{* *}\end{array}$

$\begin{array}{lllllll}-0.073(0.191) & -1.093(0.167)^{* *} & 0.524 & (0.037)^{\star *} & 1.762 & (0.215)^{* *}\end{array}$

$1.260(0.219)^{* *}-1.573(0.154)^{* *} \quad 0.216(0.033)^{\star *} \quad 1.374(0.195)^{\star *}$

$\begin{array}{llllll}-0.592(0.207)^{*}-1.466 & (0.193)^{* *} & 0.066 & (0.046) & 2.321 & (0.279)^{* *}\end{array}$

$\begin{array}{llllll}-1.119 & (0.289)^{* *}-0.963(0.353) & -0.772 & (0.087)^{\star *} & 3.848 & (0.542)^{\star *}\end{array}$

- north $\quad-0.989(0.203)^{*}$

- east $\quad-0.509(0.157)^{* *}$

- south $\quad-0.570(0.160)^{*}$

n.a. $=$ not applicable

western part of the Netherlands) also plays a role in these outcomes. In the west wages are significantly higher than in the other parts of the Netherlands, amounting to 164 guilders difference with the mean monthly wages in the north. Those who found a job abroad earn the highest wages with a difference of 677 guilders compared to the monthly wages in the west.

Table 5 presents the residual variance components at the different levels, after taking account of the student and regional factors. We note that the residual variance at the college level for "job entry" has dropped considerably. The total residual variance now 
amounts to 0.193 , which means that $30 \%$ of the original residual variance at the three higher levels is explained by student factors or region. There is no residual variance left at the college level, indicating that differences between institutes of higher vocational education must be attributed to the effects of a department, rather than the effect of the college as a whole. To give an example, a college may have a relatively well performing technics department, and at the same time a relatively bad performing health department. The performance of the different departments within a college is unrelated to each other. A part of the department effects varies over the years. The stability of the department effects, after controlling for student and regional factors, can now be estimated to be 0.68 $(=0.132 /(0.061+0.132))$.

Table 5

Results of the (logistic) 4-level analyses for 'net' performance indicators; residual variance components

\begin{tabular}{lcccc}
\hline & Job entry & Level of job & Wages per hour & Monthly wages \\
\hline & & & 15.240 & 0.360 \\
student level & n.a. & n.a. & 0.126 & 0.004 \\
year level & 0.059 & 0.000 & 0.000 & 0.000 \\
department level & 0.144 & 0.055 & 0.000 & 0.003 \\
college level & 0.000 & 0.000 & & \\
\hline
\end{tabular}

For "level of job" we note results very similar to the former model. There is no residual variance at year or college level. Introducing student and regional variables causes only a very small drop in the residual variance at the department level. Only $2 \%$ of the original residual variance at this level is accounted for by these variables.

For "hourly wages" and "monthly wages" the model hardly improves by introducing the student and regional variables. In the case of "hourly wages" the drop in residual variances at all levels is only $5 \%$. The residual variances at department and college level remain zero: there are no systematic differences between departments or colleges in this respect. In the case of "monthly wages", introduction of the student and regional variables 'explains' $6 \%$ of the original residual variance. There remain very small systematic differences in labour market outcomes between colleges and departments, but a large part of these effects is due to variation over time.

The residual effects at the department level may be regarded as the performance indicator of a department regarding the labour market outcomes. In this respect, it is interesting to compare the 'gross' performance with the 'net' performance, that is the performance after taking account of the student and regional factors. Table 6 presents the correlations between the gross and net performance indicators. One conclusion that may be drawn, is that the correlation between gross and net indicators is high, but not perfect. In the case of "job entry" the correlation between the two indicators is 0.77 , indicating that only $59 \%$ of the differences in the net outcomes of a department is correctly predicted by the gross 
outcomes. In the case of "monthly wages" the predictive value of the gross outcomes is $67 \%$, while in the case of "level of job" the predictive value of gross outcomes is almost perfect. This can also be illustrated by the rankings presented in the Appendix. In the case of "job entry" in 11 out of 97 cases the ranking of gross and net outcomes differs more than 10 or more percentile points, turning a relatively well-performing department into a relatively bad one and vice versa. In the case of "monthly wages" this happens only in 8 out of 97 cases, while in the case of "level of job" it does not happen at all.

Table 6

Spearman rank correlations between department level quality indicators

\begin{tabular}{|c|c|c|c|c|c|c|}
\hline job entry gross & 1.000 & & & & & \\
\hline job entry net & $0.752^{\star *}$ & 1.000 & & & & \\
\hline level of job gross & 0.018 & 0.112 & 1.000 & & & \\
\hline level of job net & -0.023 & 0.068 & $0.927^{*}$ & 1.000 & & \\
\hline monthly wages gross & $0.240^{*}$ & 0.071 & 0.097 & 0.100 & 1.000 & \\
\hline monthly wages net & -0.060 & 0.073 & 0.246 & 0.230 & $0.600^{* *}$ & 1.000 \\
\hline & $\begin{array}{r}\text { job entry } \\
\text { gross }\end{array}$ & $\begin{array}{r}\text { job entry } \\
\text { net }\end{array}$ & $\begin{array}{r}\text { level of } \\
\text { job gross }\end{array}$ & $\begin{array}{l}\text { level of } \\
\text { job net wag }\end{array}$ & $\begin{array}{l}\text { montly } \\
\text { es gross }\end{array}$ & $\begin{array}{c}\text { monthly } \\
\text { wages net }\end{array}$ \\
\hline
\end{tabular}

Interesting are the low correlations between the outcomes of the three different types of net indicators: "job entry", "level of job" and "monthly wages". The correlation between the first and the second is 0.07 , between the first and the third 0.07 and between the second and third 0.23 . In other words, having a good score on one quality indicator has no predictive value for the score on another indicator. Put alternatively, what makes a department effective in one area, does not necessarily makes it effective in another area. Again this can be illustrated by the rankings of the departments in the appendix. Take for example the departments for pedagogics, i.e. the training course 'teacher primary education'. Here we can see college 94 having good scores on the first net quality indicator "job entry", but its score on the other two net performance indicators is on average. On the other hand, we see that college 54 has a low percentile rank for "job entry", but it scores on average as well on the other two net performance indicators. None of the departments does either extremely well or extremely poor on two or three net performance indicators.

\section{Summary and conclusions}

The main results can be summarized as follows:

1) There are systematic differences between departments and colleges in the following quality indicators with respect to the labour market outcomes of their graduates: chance of being less than 3 months unemployed; chance of acquiring a job which 
matches the educational level attained and gross monthly wages.

2) These effects remain significant even after controlling for student and regional factors. They are due to differences between departments rather than differences between colleges.

3) The department effects are rather stable in the case of chances of being less than 3 months unemployed and of acquiring a job which matches the educational level attained. In the case of monthly wages the effects vary considerably over time.

4) The net quality indicator of a department (i.e. the outcome after controlling for student and regional factors) differs considerably from the gross quality indicator, except in the case of level of job.

5) Departments which effectively improve their graduates' chances of finding a job are not necessarily also effective in improving the chances of finding high quality work, as indicated by level of job or wage.

What are the theoretical and empirical implications of the previous analysis?

First of all, it seems important to extend educational effectiveness research to the area of labour market outcomes. Departments do have an effect on the labour market success of their graduates. The leading theories within the educational effectiveness research, however, seem to bear only little relevance with regard to these labour market outcomes. To build a coherent theoretical framework, theories of effective instruction and effective educational institutions need to be integrated with theories about the role of education in selection processes on the labour market (Van der Velden et al., 1989).

The analysis shows that departments which are effective in the area of improving their graduates' employment chances, are not necessarily effective in the area of improving the quality of the jobs which the graduates hold. This is in line with previous analyses of Van der Velden and Wieling (1994) and Van Smoorenburg and Van der Velden (1995), who showed that the labour market position of types of education can be distinguished in two major dimensions: employment chances and quality of work. These dimensions can be shown to be theoretically and empirically independent. The fact that these two dimensions are also relevant in the analysis of differences between institutes, stresses the importance of this distinction. In the theoretical framework it is important to elaborate on the factors which make an institute more effective in one area and which factors are of importance in the other area.

Bearing in mind the growing importance of external quality control both for higher education as well as for secondary education, implicates that there is an increasing need for valid and reliable information about the performance with respect to labour market outcomes of institutes of education. In this respect, the added value of an institute, i.e. the performance after controlling for input or regional factors, is of particular interest. Given the fact that the net performance of an institute quite often differs considerably from the gross performance, institutes should only be judged on the basis of this net performance. The model presented 
here offers a way of calculating these 'net' quality indicators.

\section{References}

Becker, G.S. (1975), Human Capital: A Theoretical and Empirical Analysis with Special Reference to Education, 2nd edition, New York, NBER.

Bosker, R.J. and W.H.A. Hofman (1994), 'School effects on drop out: A multi-level logistic approach to assessing school-level correlates of drop out of minorities,' Tijdschrift voor Onderwijsresearch, 19, pp. 50-64.

Bryk, A.S. and S.W. Raudenbush (1992), Hierarchical Linear Models, Newbury Park, Sage.

Coleman, J.S., E.Q. Campbell, C.F. Hobson, J. McPartland, A.M. Mood, F.D. Weifeld, and R.L. York (1966), Equality of educational opportunity. Washington, DC, U.S. Government Printing Office.

Croxford, L. and M. Cowie (1996), The Effectiveness of Grampian Secondary Schools, (a report to Grampian Education Authority).

Dolan, C.R. and R.M. Schmidt (1994), 'Modeling Institutional Production of Higher Education,' Economics of Education Review, 13, pp. 197-213.

European Commission (1993), White paper. Bruxelles, EU.

Fitz-Gibbon, C.T. (1996), Monitoring education: indicators, quality and effectiveness, London, Cassell.

Glebbeek, A.C. (1989), 'De arbeidsmarktpositie van opleidingen,' Tijdschrift voor Arbeids vraagstukken, 4, pp. 75-89.

Goldstein, H. and M.J.R. Healy (1995), 'The graphical presentation of a collection of means,' Journal of the Royal Statistical Society, 158, pp. 1-3.

Goldstein, H. and K. Myers (1996), 'Freedom of information: Towards a code of ethics for performance indicators,' Research Intelligence, 57, pp. 12-16.

Goldstein, H. (1995), Multilevel Statistical Models, London, Edward Arnold.

Hanushek, E.A. (1986), 'The economics of schooling: Production and efficiency in public schools.' Journal of Economic Literature, 24, 1141-1177.

Hedges, L.V., R.D. Laine and R. Greenwald (1994), 'Does money matter? A meta-analysis of studies of the effects of differential school inputs on student outcomes,' Educational Researcher, 
23, pp. 5-14.

IRDAC, Industrial Reserach and Development Advisory Committee of the Commission of the European Communities (1990), Skills Shortages in Europe, Bruxelles, EU.

Jager, G. de (1994), Invloedrijke beelden, Over de betekenis van paradigma's en hun invloed op de besturing van hogescholen, Rotterdam, Erasmus Universiteit.

Longford, N.T. (1993), Random Coefficient Models, Oxford, Clarendon Press.

Loo, P.J.E. van de, G.W.M. Ramaekers and R.K.W. van der Velden (1992), De arbeidsmarktpositie van afgestudeerden van het hoger beroepsonderwijs, HBO-Monitor 1991, Den Haag, HBO-Raad.

Loo, P.J.E. van de, R.K.W. van der Velden and M.H. Wieling (1993), De arbeidsmarktpositie van afgestudeerden van het hoger beroepsonderwijs, HBO-Monitor 1992, Den Haag, HBO-Raad.

Loo, P.J.E. van de, and R.K.W. van der Velden (1994), De arbeidsmarktpositie van afgestudeerden van het hoger beroepsonderwijs, HBO-Monitor 1993, Den Haag, HBO-Raad.

Ministerie van Onderwijs, Cultuur en Wetenschappen (1985), Hoger Onderwijs: Autonomie en Kwaliteit (HOAK-nota). Zoetermeer, Ministerie van Onderwijs en Wetenschappen.

Ministerie van Onderwijs, Cultuur en Wetenschappen (1995), De school als lerende organisatie, Den Haag, SDU.

Monk, D.H. (1989), 'The education production function: Its evolving role in policy analysis.' Educational Evaluation and Policy Analysis, 11, pp. 31-45.

Morrison, H.G, S.P. Magennis and L.J. Carey (1995), 'Performance indicators and league tables: A call for standards,' Higher Education Quarterly, 49, pp. 128-45.

OECD (1996), Education at a Glance, Paris, OECD.

O'Leary, J. (ed.) (1995), The Times Good University Guide 1995-1996, Times Books, London.

Robst, J. (1995), 'College quality and overeducation,' Economics of Education Review, 14, pp. 221-228.

Scheerens, J. and R.J. Bosker (1997), The foundations of educational effectiveness, Oxford, Pergamon.

Schultz, T.W. (1961), 'Investment in Human Capital,' American Economic Review, 51, pp. $1-17$.

Segers, M.S.R. (1993), Kwaliteitsbewaking in het hoger onderwijs, Een exploratieve studie naar prestatie-indicatoren in theorie en praktijk, Utrecht, Uitgeverij Lemma BV.

Smoorenburg, M.S.M. and R.K.W. van der Velden (1995), The Labour Market Positions of 
Types of Education: Dimensions and Stability. Maastricht, ROA.

Snijders, T.A.B. and R.J. Bosker (1993), 'Standard errors and sample sizes for two-level research,' Journal of Educational Statistics, 18, pp. 237-59.

Tuijnman, A.C. and T.N. Postlethwaite (1994) (eds.), Monitoring the standards of education, Oxford, Pergamon.

Velden, R.K.W. van der, P. Edelenbos and Th. Mensen (1989), Letteren en arbeidsmarkt, Zoetermeer, Ministerie van Onderwijs en Wetenschappen.

Velden, R.K.W. van der and M.H. Wieling (1994), De arbeidsmarktkansen per opleiding, in H. Scholten en S.C. de Groot (red.), Arbeidsmarkt en Sociale Zekerheid, Beleid in Beweging, Tilburg, IVA, pp. 106-114.

West, A., H. Pennel, S. Thomas and P. Sammons (1995), The origins and development of the European Community - Educational Indicators Project, Paper for presentation at the European Conference on Educational Research.

Willms, J.D. (1992), Monitoring school performance: a guide for educators, Washington, Falmer Press.

Willms, J.D. and S.W. Raudenbush (1989), 'A longitudinal hierarchical linear model for estimating school effects and their stability,' Journal of Educational Measurement, 26, pp. 209232.

Willms, J.D. and A.C. Kerkhoff (1995), 'The challenge of developing new educational indicators,' Educational Evaluation and Policy Analysis, 17, pp. 113-131.

Wong, G.Y. and W.M. Mason (1985), 'The hierarchical logistic regression model for multilevel analysis,' Journal of the American Statistical Association, 80, pp. 513-524.

Yorke, M. (1997), 'A good league table guide?,' Quality Assurance in Education, 5, pp. 61-72. 


\section{Appendix}

'Conservative' percentile ranks for departments on 6 performance indicators ${ }^{1)}$

(the table is ordered according to the ranking on gross monthly wages within each study)

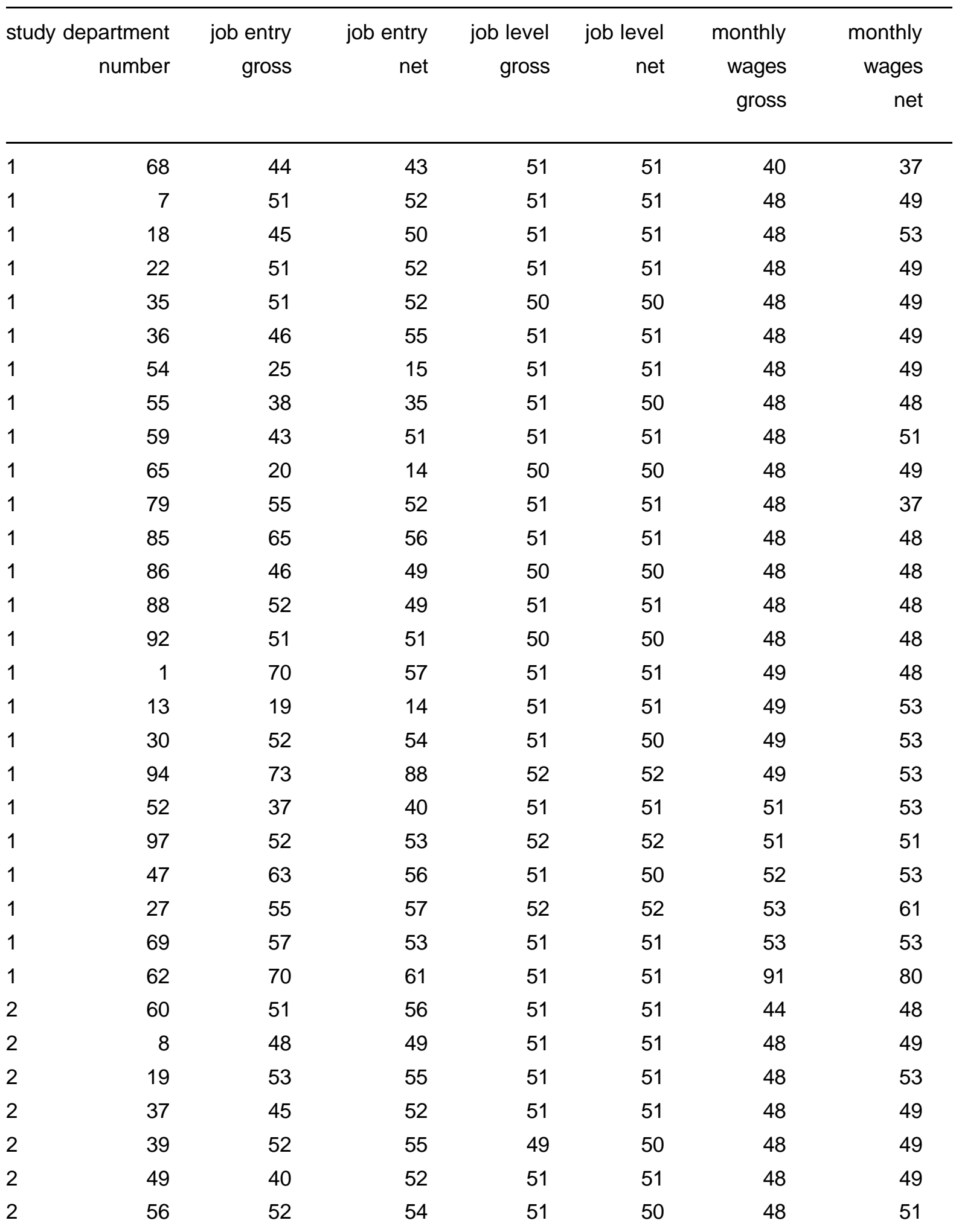




\begin{tabular}{|c|c|c|c|c|c|c|}
\hline $\begin{array}{r}\text { study department } \\
\text { number }\end{array}$ & $\begin{array}{r}\text { job entry } \\
\text { gross }\end{array}$ & $\begin{array}{r}\text { job entry } \\
\text { net }\end{array}$ & $\begin{array}{r}\text { job level } \\
\text { gross }\end{array}$ & $\begin{array}{r}\text { job level } \\
\text { net }\end{array}$ & $\begin{array}{r}\text { monthly } \\
\text { wages } \\
\text { gross }\end{array}$ & $\begin{array}{r}\text { monthly } \\
\text { wages } \\
\text { net }\end{array}$ \\
\hline 74 & 52 & 52 & 52 & 51 & 48 & 49 \\
\hline 78 & 52 & 53 & 51 & 51 & 48 & 51 \\
\hline 82 & 40 & 19 & 49 & 50 & 48 & 48 \\
\hline 87 & 52 & 56 & 51 & 51 & 48 & 48 \\
\hline 89 & 54 & 51 & 51 & 51 & 48 & 48 \\
\hline 2 & 58 & 52 & 52 & 53 & 49 & 48 \\
\hline 14 & 44 & 51 & 51 & 51 & 49 & 53 \\
\hline 31 & 48 & 52 & 50 & 50 & 49 & 53 \\
\hline 53 & 46 & 52 & 52 & 52 & 51 & 53 \\
\hline 44 & 45 & 30 & 51 & 51 & 53 & 49 \\
\hline 70 & 52 & 52 & 51 & 51 & 53 & 53 \\
\hline 61 & 40 & 49 & 51 & 51 & 44 & 48 \\
\hline 12 & 52 & 51 & 32 & 33 & 48 & 37 \\
\hline 17 & 52 & 53 & 51 & 51 & 48 & 49 \\
\hline 23 & 51 & 52 & 51 & 51 & 48 & 49 \\
\hline 38 & 38 & 49 & 51 & 51 & 48 & 49 \\
\hline 40 & 45 & 52 & 54 & 53 & 48 & 49 \\
\hline 48 & 24 & 45 & 51 & 51 & 48 & 51 \\
\hline 57 & 52 & 53 & 51 & 51 & 48 & 51 \\
\hline 73 & 52 & 51 & 51 & 51 & 48 & 49 \\
\hline 77 & 36 & 41 & 50 & 50 & 48 & 49 \\
\hline 84 & 57 & 52 & 51 & 50 & 48 & 48 \\
\hline 90 & 68 & 57 & 51 & 51 & 48 & 48 \\
\hline 93 & 55 & 57 & 54 & 52 & 48 & 51 \\
\hline 3 & 58 & 52 & 47 & 49 & 49 & 48 \\
\hline 32 & 49 & 52 & 51 & 51 & 49 & 53 \\
\hline 51 & 51 & 49 & 51 & 51 & 51 & 51 \\
\hline 45 & 57 & 53 & 52 & 52 & 53 & 49 \\
\hline 25 & 52 & 52 & 42 & 44 & 33 & 11 \\
\hline 67 & 48 & 51 & 53 & 52 & 44 & 48 \\
\hline 9 & 51 & 52 & 51 & 51 & 48 & 49 \\
\hline 20 & 54 & 56 & 52 & 52 & 48 & 53 \\
\hline 24 & 48 & 49 & 53 & 53 & 48 & 49 \\
\hline 28 & 52 & 52 & 52 & 52 & 48 & 49 \\
\hline 41 & 46 & 49 & 53 & 52 & 48 & 49 \\
\hline 75 & 61 & 57 & 42 & 42 & 48 & 49 \\
\hline
\end{tabular}


study department job entry job entry job level job level monthly monthly number gross net gross net wages wages gross net

\begin{tabular}{|c|c|c|c|c|c|c|c|}
\hline 4 & 80 & 53 & 52 & 51 & 51 & 48 & 37 \\
\hline 4 & 91 & 57 & 52 & 51 & 51 & 48 & 48 \\
\hline 4 & 4 & 59 & 52 & 9 & 11 & 49 & 48 \\
\hline 4 & 33 & 52 & 55 & 52 & 52 & 49 & 53 \\
\hline 4 & 95 & 48 & 41 & 52 & 52 & 49 & 53 \\
\hline 4 & 71 & 52 & 52 & 51 & 51 & 53 & 53 \\
\hline 4 & 63 & 52 & 45 & 51 & 51 & 91 & 80 \\
\hline 5 & 6 & 48 & 49 & 51 & 51 & 48 & 51 \\
\hline 5 & 10 & 47 & 37 & 51 & 51 & 48 & 49 \\
\hline 5 & 21 & 52 & 52 & 51 & 51 & 48 & 53 \\
\hline 5 & 26 & 52 & 52 & 50 & 50 & 48 & 48 \\
\hline 5 & 29 & 56 & 57 & 47 & 48 & 48 & 49 \\
\hline 5 & 42 & 49 & 52 & 51 & 51 & 48 & 49 \\
\hline 5 & 50 & 40 & 52 & 51 & 51 & 48 & 49 \\
\hline 5 & 58 & 47 & 49 & 51 & 51 & 48 & 51 \\
\hline 5 & 76 & 60 & 57 & 51 & 51 & 48 & 49 \\
\hline 5 & 81 & 58 & 54 & 51 & 51 & 48 & 37 \\
\hline 5 & 15 & 36 & 45 & 51 & 51 & 49 & 53 \\
\hline 5 & 34 & 46 & 49 & 51 & 51 & 49 & 53 \\
\hline 5 & 96 & 52 & 52 & 51 & 51 & 49 & 53 \\
\hline 5 & 46 & 52 & 52 & 51 & 51 & 53 & 49 \\
\hline 5 & 72 & 52 & 49 & 51 & 51 & 53 & 53 \\
\hline 5 & 64 & 65 & 54 & 50 & 50 & 91 & 80 \\
\hline 6 & 16 & 42 & 49 & 51 & 51 & 48 & 48 \\
\hline 6 & 43 & 47 & 52 & 51 & 51 & 48 & 49 \\
\hline 6 & 66 & 47 & 52 & 51 & 51 & 48 & 49 \\
\hline 6 & 83 & 57 & 53 & 51 & 51 & 48 & 51 \\
\hline 6 & 5 & 63 & 53 & 51 & 51 & 49 & 48 \\
\hline 6 & 11 & 48 & 49 & 50 & 50 & 51 & 51 \\
\hline
\end{tabular}

1): A department is a unique combination of college number and study

Legend: study: $\quad \begin{aligned} 1 & =\text { pedagogics } & & \text { (teacher for primary education) } \\ 2 & =\text { technics } & & \text { (mechanical engineering) } \\ 3 & =\text { health studies } & & \text { (nurse training) } \\ 4 & =\text { economics } & & \text { (business administration) } \\ 5 & =\text { social studies } & & \text { (social work) } \\ 6 & =\text { fine arts } & & \text { (training for musician) }\end{aligned}$

